Review

\title{
Focus on Vitamin D, Inflammation and Type 2 Diabetes
}

\author{
Carlos Eduardo Andrade Chagas ${ }^{1}$, Maria Carolina Borges ${ }^{2}$, Lígia Araújo Martini ${ }^{2}$ and \\ Marcelo Macedo Rogero ${ }^{2, *}$
}

1 Center for Nutrition Practice and Research, Department of Education, Institute of Biosciences, São Paulo State University, Botucatu, SP 18618-970, Brazil; E-Mail: cchagas@ibb.unesp.br

2 Department of Nutrition, School of Public Health, University of Sao Paulo, Sao Paulo 01246-904, Brazil; E-Mail: mcarolborges@usp.br (M.C.B.); 1martini@usp.br (L.A.M.)

* Author to whom correspondence should be addressed; E-Mail: mmrogero@usp.br; Tel.: +55-11-3061-7850; Fax: +55-11-3061-7705.

Received: 2 December 2011; in revised form: 29 December 2011 / Accepted: 9 January 2012 / Published: 20 January 2012

\begin{abstract}
The initial observations linking vitamin D to type 2 diabetes in humans came from studies showing that both healthy and diabetic subjects had a seasonal variation of glycemic control. Currently, there is evidence supporting that vitamin D status is important to regulate some pathways related to type 2 diabetes development. Since the activation of inflammatory pathways interferes with normal metabolism and disrupts proper insulin signaling, it is hypothesized that vitamin D could influence glucose homeostasis by modulating inflammatory response. Human studies investigating the impact of vitamin D supplementation on inflammatory biomarkers of subjects with or at high risk of developing type 2 diabetes are scarce and have generated conflicting results. Based on available clinical and epidemiological data, the positive effects of vitamin D seem to be primarily related to its action on insulin secretion and sensitivity and secondary to its action on inflammation. Future studies specifically designed to investigate the role of vitamin D on type 2 diabetes using inflammation as the main outcome are urgently needed in order to provide a more robust link between vitamin $\mathrm{D}$, inflammation and type 2 diabetes.
\end{abstract}

Keywords: vitamin D; inflammation; diabetes 


\section{Introduction}

Type 2 diabetes is one of the main noncommunicable chronic diseases and its complications have become a major cause of morbidity and mortality worldwide. It has been estimated that 285 million individuals have diabetes, most of them type 2 diabetes [1]. Vitamin D deficiency is also considered a public health problem around the world. In 2008, it was estimated that 1 billion individuals presented vitamin D insufficiency or deficiency [2].

Much evidence suggested that vitamin $\mathrm{D}$ is involved in several mechanisms in addition to bone metabolism [3] and its role in abnormal glucose metabolism as well as in type 2 diabetes has been demonstrated $[4,5]$. A recent review indicates that vitamin $\mathrm{D}$ deficiency may predispose to glucose intolerance, altered insulin secretion and type 2 diabetes [6], either through a direct action via vitamin D receptor (VDR) activation or indirectly via calcemic hormones and also via inflammation [7].

Furthermore, in observational studies the risk of diabetes was negatively associated with increased vitamin D concentrations [6,8]. In fact, Mitri et al. [9], in a systematic review, confirmed such evidence by evaluating vitamin D intake and 25-hydroxyvitamin D (25OHD) levels. In 8 observational studies, vitamin D intake $>500$ international units (IU)/day decreased the risk of type 2 diabetes by $13 \%$ compared with vitamin D intake $<200$ IU/day. Individuals with the highest 25OHD status ( $>25 \mathrm{ng} / \mathrm{mL}$ ) had a $43 \%$ lower risk of developing type 2 diabetes (95\% confidence interval 24-57\%) compared with those in the lowest group $(<14 \mathrm{ng} / \mathrm{mL})$.

On the other hand, information pooled from vitamin D intervention trials lack conclusive evidence. In the same systematic review [9], no effect of vitamin D supplementation on glycemic outcomes were demonstrated in post hoc analysis from eleven trials. However, it has been observed some potential benefits of vitamin D supplementation in non-diabetics [10]. There are several potential reasons for the conflicting findings from human studies of vitamin D and diabetes, which are discussed in the present review.

Inflammation participates in host defenses against infectious agents and injury, but it also contributes to the pathophysiology of many chronic diseases. There is evidence for a direct link between type 2 diabetes and subclinical inflammation, which supports the concept that such disease is, at least in part, an inflammatory condition [11]. Moreover, it has been observed that the relationship between vitamin $\mathrm{D}$ and low-intensity chronic inflammation and insulin resistance in type 2 diabetes can be mediated in part by the immune-modulating properties of the $1,25(\mathrm{OH})_{2} \mathrm{D}_{3}$, which is able to downregulate the production of pro-inflammatory cytokines [12].

Considering that inflammatory status as well vitamin D insufficiency create an environment conducive to the development and progression of several diseases, the present review will focus on the associations observed between vitamin $\mathrm{D}$ status and its potential immune-modulating effects in the metabolism of type 2 diabetes biomarkers.

\section{Inflammation, Insulin Resistance and Type 2 Diabetes}

Chronic low-grade inflammation, frequently observed in obese individuals, is involved in the development of insulin resistance, which increases the risk of type 2 diabetes. The first link between obesity, inflammation and insulin action came from a study developed by Hotamisligil et al. [13], which demonstrated that tumor necrosis factor (TNF)- $\alpha$ mRNA expression in the adipose tissue of 
obese animal (fa/fa rat and ob/ob mouse) was increased and that the neutralization of TNF- $\alpha$ improved insulin action on glucose uptake. It is now acknowledged that not only TNF- $\alpha$ but an array of inflammatory cytokines are elevated in obese tissues, including interleukin (IL)-1 $\beta$, IL-6, monocyte chemoattractant protein (MCP)-1, and others [14]. A major finding advancing in the understanding of obesity-induced inflammation was the discovery that immune cells, in particular adipose tissue infiltrated macrophages, largely contribute to the increased production of inflammatory mediators $[15,16]$.

There is strong evidence that activation of inflammatory pathways interferes with normal metabolism and disrupts proper insulin signalling [17]. Briefly, insulin binding to its receptor triggers tyrosine phosphorylation of insulin receptor substrates (IRS), leading to activation of phosphatidylinositol 3-kinase (PI3K)-Akt pathway, which is responsible for insulin action on glucose uptake and suppression of gluconeogenesis [18]. In response to inflammatory signals, c-jun $N$-terminal kinase (JNK) and inhibitor of $\kappa \mathrm{B}$ kinase (IKK) are activated and can target IRS-1 for serine phosphorylation, which inhibits the insulin receptor signalling cascade. Not only JNK and IKK, but also other kinases, such as protein kinase $\mathrm{C}$ (PKC)- $\theta$, can inhibit IRS-1 through serine phosphorylation, implying that activation of diverse cellular networks can antagonize insulin signalling. Apart from inhibiting insulin action through targeting insulin signalling molecules, JNK and IKK can also regulate downstream transcriptional programs through the transcription factors activator protein (AP)-1 and nuclear factor $(\mathrm{NF})-\mathrm{\kappa B}$, respectively, resulting in increased expression of proinflammatory cytokines, such as IL-1 $\beta$ and TNF- $\alpha[17,19,20]$. These cytokines can target cell membrane receptors, feeding into inflammatory response and exacerbating insulin resistance. Another important molecular mediator that link proinflammatory cytokine to inhibition of insulin signalling are suppressors of cytokine signalling (SOCS) 1 and 3, induced by IL-6, which lead to ubiquitinylation and degradation of IRS proteins [21].

Insulin resistance can also be triggered by the presence of metabolic stressors, such as high blood non-esterified fatty acids (NEFA) levels, which compromises insulin sensitivity by reducing the action of this hormone in peripheral tissues, such as the liver, skeletal muscle and adipose tissue [22,23]. Another systemic factor influencing insulin sensitivity is adiponectin. Plasma adiponectin levels in humans are negatively correlated with fasting insulin concentrations and positively correlated with insulin sensitivity, suggesting that the hormone is able to sensitize peripheral tissues to insulin action. However, certain inflammatory mediators, such as TNF-a and IL-6, which have been shown to be elevated in obese and insulin resistant individuals, are inhibitors of adipose tissue adiponectin mRNA expression and protein secretion [24]. In addition, adiponectin impairs the production of proinflammatory cytokines, such as TNF-a and interferon-g (IFN-g), in human macrophages and reduces their phagocytic capacity while inducing the production of the anti-inflammatory mediators IL-10 and IL-1 receptor antagonist (IL-1RA) by human monocytes, monocyte-derived macrophages and dendritic cells [25].

\section{Vitamin D and Inflammation}

During the exposure to sunlight, ultraviolet B (UVB) photons penetrate into the skin and are absorbed by 7-dehydrocholesterol inducing the formation of previtamin D (Figure 1). This is an unstable form of vitamin $\mathrm{D}$ that rapidly undergoes rearrangement to form vitamin $\mathrm{D}_{3}$ (cholecalciferol). Vitamin $\mathrm{D}_{2}$ (ergocalciferol) is the form of vitamin $\mathrm{D}$ that occurs in plants and is used to fortify certain foods, such as fluid milk. Both vitamin D forms eventually enter the circulation bound to a vitamin D binding protein and are metabolized in the liver by the vitamin D-25-hydroxylase enzyme (25-OHase 
or CYP27A1) to 25-hydroxyvitamin D (calcidiol), the main vitamin D form circulating in plasma and a substrate for production of the hormonally active metabolite 1,25 -dihydroxyvitamin $\mathrm{D}, 1,25(\mathrm{OH})_{2} \mathrm{D}_{3}$ (calcitriol) [26].

Figure 1. Cutaneous synthesis and metabolism of vitamin D. In the skin, 7-dehydrocholesterol (DHC) can be converted to pre-vitamin D in response to ultraviolet B (UVB) radiation from the sun. Pre-vitamin D is then converted to vitamin D. Continued cutaneous exposure to UVB can produce various photoproducts (not shown) from both pre-vitamin D and vitamin D. Vitamin D (and other vitamin D metabolites) are carried in the blood by a $50-\mathrm{kD}$ vitamin D-binding protein (DBP). Vitamin D is converted in the liver by the P450 enzyme CYP27A1 to 25-hydroxyvitamin D (25OHD), which is the major form of vitamin D found in the blood. In the kidney, another P450 enzyme, CYP27B1, adds a hydroxyl group at the $\mathrm{C}-1$ position of $25 \mathrm{OHD}$ to form the active vitamin $\mathrm{D}$ hormone 1,25-dihydroxyvitamin $\mathrm{D}$, or $1,25(\mathrm{OH})_{2} \mathrm{D}_{3}$. Both $25 \mathrm{OHD}$ and $1,25(\mathrm{OH})_{2} \mathrm{D}_{3}$ are hydroxylated at C-24 by CYP24, which initiates their inactivation and metabolic breakdown. Vitamin D receptor (VDR)-mediated gene expression in response to $1,25(\mathrm{OH})_{2} \mathrm{D}_{3}$ occurs in many different tissues, including classical vitamin $\mathrm{D}$ target organs such as intestine, bone, and kidney. The active vitamin $\mathrm{D}$ hormone can also stimulate very rapid changes at the plasma membrane that are mediated by a $1,25(\mathrm{OH})_{2} \mathrm{D}_{3}$ membrane-associated rapid response steroid hormone binding protein (MARRS). Adapted from Martini and Wood [26].

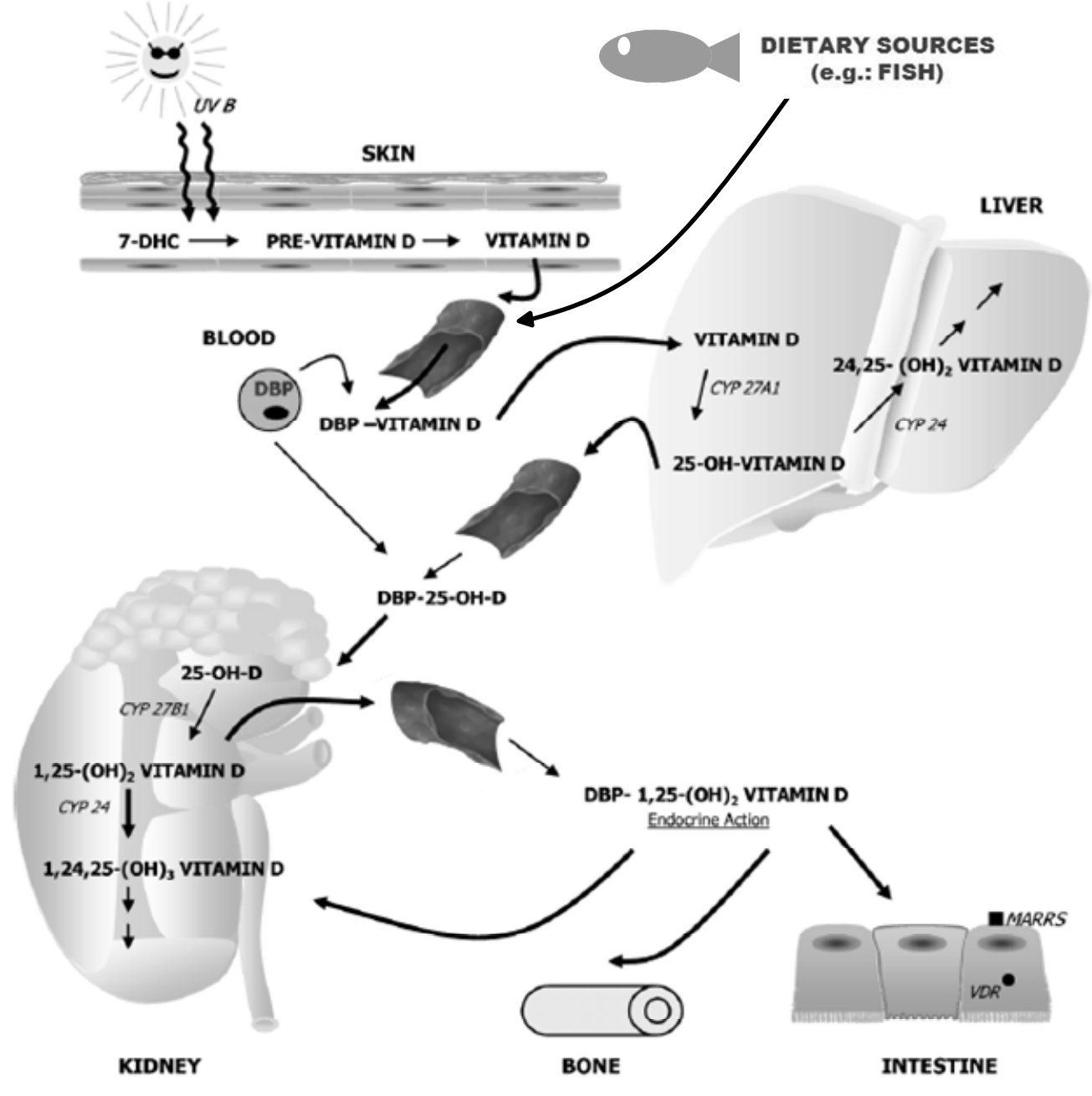


It is recognized that VDR, the receptor of the steroid hormone $1,25(\mathrm{OH})_{2} \mathrm{D}_{3}$, is widely distributed in more than 38 tissues, where it clearly controls vital genes related to bone metabolism, oxidative damage, chronic diseases and inflammation [27].

VDR is constitutively expressed by macrophages and dendritic cells, which suggests that vitamin D plays an important role in the modulation of inflammatory response. The $1,25(\mathrm{OH})_{2} \mathrm{D}_{3}$ can be synthesized by both cell types, since they express the enzymes 25 -hydroxylase and 1 $\alpha$-hydroxylase, which enables the production of $25 \mathrm{OHD}$ and $1,25(\mathrm{OH})_{2} \mathrm{D}_{3}$, respectively [28,29]. In macrophages and dendritic cells, the enzyme $1 \alpha$-hydroxylase is predominantly regulated by inflammatory mediators, such as interferon (IFN)- $\gamma$ and lipopolysaccharides (LPS) [30].

Macrophages are cells with a large capacity for cytokine production, in particular TNF- $\alpha$, which is one of the most important products released from these cells [31]. Transcriptional activation of the TNF- $\alpha$ gene in macrophages is largely dependent on the NF- $\kappa \mathrm{B}$-dependent transcriptional activation, which is a major regulator of immune, inflammatory and stress responses [32]. In LPS-stimulated murine macrophages, $1,25(\mathrm{OH})_{2} \mathrm{D}_{3}$ up-regulates the inhibitor of NF- $\kappa \mathrm{B}(\mathrm{I} \kappa \mathrm{B}-\alpha)$ by increasing mRNA stability and decreasing IkB- $\alpha$ phosphorylation. The increase in I $\mathrm{B}-\alpha$ levels leads to a reduction in nuclear translocation of NF- $\kappa \mathrm{B}$, thereby causing a decline in activity. In view of the key role of NF- $\mathrm{B}$ as transcription factor of inflammatory mediators, it should be suggested that $1,25(\mathrm{OH})_{2} \mathrm{D}_{3}$ has anti-inflammatory action in macrophages [33]. Furthermore, $1,25(\mathrm{OH})_{2} \mathrm{D}_{3}$ suppresses the expression of TLR2 and TLR4 protein and mRNA in human monocytes in a time- and dose-dependent fashion (Figure 2) [34]. Incubation of isolated monocytes with $1,25(\mathrm{OH})_{2} \mathrm{D}_{3}$ attenuates the expression of proinflammatory cytokines involved in insulin resistance such as IL-1, IL-6 and TNF-alpha in type 2 diabetic patients [35]. This fact may be related to the downregulation of NF- $\kappa B$ activity, as suggested by studies with P388D1 cells, a murine macrophage-like cell line [33,36].

Figure 2. Vitamin D modulates the inflammatory response of immune cells, such as macrophages and monocytes. Adapted from Borges et al. [37] (IKK: IкB kinase; IкB: inhibitor of NF-kB; LPS: lipopolysaccharides; TLR: Toll-like receptor).

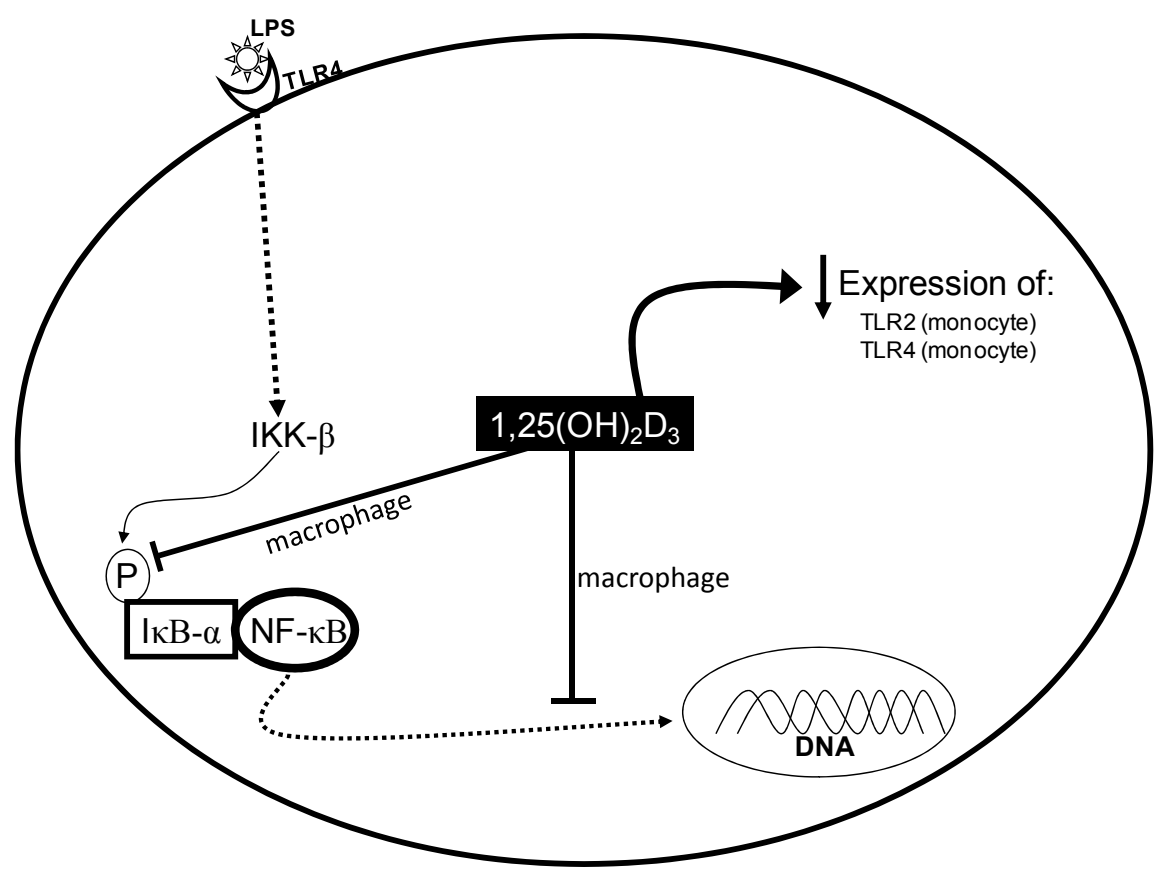


Despite the fact that experimental data support the involvement of vitamin D in modulating the inflammatory response, clinical and epidemiological studies are still scarce. Observational studies have generated conflicting results. Some cross-sectional studies indicate that hypovitaminosis D is associated with higher serum levels of inflammatory biomarkers, such as IL-6, TNF- $\alpha$, and C-reactive protein (CRP), in healthy [38-41] and in obese subjects [42], while others could not confirm these findings [43-46]. Given the observational design, cross-sectional studies cannot prove causality or fully discount residual confounding by unmeasured variations. In this context, randomized placebo-controlled clinical trials are extremely useful to address the hypothesis that hypovitaminosis D might induce a higher inflammatory response. Table 1 presents clinical trials investigating the effect of vitamin D supplementation on serum inflammatory biomarkers. In some diseases associated with inflammation, such as chronic heart failure, chronic kidney disease and osteoporosis, vitamin D supplementation seems to attenuate serum TNF- $\alpha$ levels and to increase serum IL-10 concentration [47-49]. In a study involving subjects with either normal or impaired fasting glucose, the combined calcium-vitamin D supplementation (500 mg calcium +700 IU cholecalciferol per day) for 3 years did not influence systemic CRP or IL-6 [50]. On the other hand, healthy overweight subjects participating in a weight-reduction program, when supplemented with vitamin D (3332 IU cholecalciferol/day for twelve months), experienced a greater decrease in serum TNF- $\alpha$ levels, but not in IL-6 and CRP concentration, when compared to placebo group [51].

Table 1. Clinical trials investigating the effect of vitamin D supplementation on serum inflammatory biomarkers.

\begin{tabular}{|c|c|c|c|}
\hline Ref. & \begin{tabular}{|c|}
$\begin{array}{c}\text { Number and characteristics } \\
\text { of subjects }\end{array}$ \\
\end{tabular} & Intervention and duration & $\begin{array}{c}\text { Vitamin D effect on } \\
\text { inflammatory serum biomarkers }\end{array}$ \\
\hline$[10]$ & $\begin{array}{l}81 \text { South Asian women with } \\
\text { insulin resistance. } \\
\text { Median serum } 25 \mathrm{OHD} \text { at } \\
\text { baseline: } 21 \mathrm{nmol} / \mathrm{L} \text {. }\end{array}$ & $\begin{array}{l}100 \mu \mathrm{g} \text { of vitamin } \mathrm{D}_{3} \text { or } \\
\text { placebo for } 6 \text { months. }\end{array}$ & No effect on C-reactive protein. \\
\hline$[47]$ & $\begin{array}{l}123 \text { patients with congestive } \\
\text { heart failure. } \\
\text { Mean serum } 25 \mathrm{OHD} \text { at the } \\
\text { baseline: } 36 \mathrm{nmol} / \mathrm{L} \text {. }\end{array}$ & $\begin{array}{l}\text { Oral supplementation } \\
\left(50 \mu \mathrm{g} / \text { day vitamin } \mathrm{D}_{3} \text { plus }\right. \\
500 \mathrm{mg} \text { of calcium }) \text { for } \\
9 \text { months. }\end{array}$ & $\begin{array}{l}\text { No differences in TNF- } \alpha \text { and } \\
\text { C-reactive protein. Significant } \\
\text { increase in interleukin } 10 .\end{array}$ \\
\hline$[48]$ & $\begin{array}{l}34 \text { haemodialysis patients. } \\
\text { Mean serum 25OHD at } \\
\text { baseline: not reported. }\end{array}$ & $\begin{array}{l}\text { Oral }(0.5 \mu \mathrm{g} / \text { day; } n=18) \text { or } \\
\text { intravenous }(1 \mu \mathrm{g} 3 \times \text { week; } \\
n=16) \text { calcitriol for } 6 \text { months. }\end{array}$ & $\begin{array}{l}\text { Oral calcitriol: No differences in } \\
\text { TNF- } \alpha \text {, interleukin } 1 \text { and } \\
\text { interleukin } 6 \text {; } \\
\text { Intravenous calcitriol: significant } \\
\text { decrease in TNF- } \alpha \text {, interleukin } 1 \\
\text { and interleukin } 6 \text {. }\end{array}$ \\
\hline [49] & $\begin{array}{l}70 \text { post-menopausal women } \\
\text { with osteoporosis. } \\
\text { Mean serum } 25 \mathrm{OHD} \text { at } \\
\text { baseline: not reported. }\end{array}$ & $\begin{array}{l}0.5 \mu \mathrm{g} / \text { day of calcitriol and } \\
1,000 \mathrm{mg} / \text { day of calcium or } \\
\text { placebo (only } 1,000 \mathrm{mg} / \text { day of } \\
\text { calcium) for } 6 \text { months. }\end{array}$ & $\begin{array}{l}\text { Significant decrease in decrease in } \\
\text { TNF- } \alpha \text { and interleukin } 1 . \\
\text { No differences in interleukin } 6 \text {. }\end{array}$ \\
\hline
\end{tabular}


Table 1. Cont.

\begin{tabular}{|c|c|c|c|}
\hline$[50]$ & $\begin{array}{l}222 \text { non-obese subjects with } \\
\text { normal fasting glucose and } \\
92 \text { non-obese with impaired } \\
\text { fasting glucose. Mean serum } \\
25 \mathrm{OHD} \text { at baseline in both } \\
\text { groups: } 76 \mathrm{nmol} / \mathrm{L} \text {. }\end{array}$ & $\begin{array}{l}700 \mathrm{IU} \text { of vitamin } \mathrm{D}_{3} \text { or placebos for } \\
3 \text { years. }\end{array}$ & $\begin{array}{l}\text { No differences in C-reactive } \\
\text { protein and interleukin } 6 .\end{array}$ \\
\hline$[51]$ & $\begin{array}{l}200 \text { healthy overweight } \\
\text { subjects. Mean serum } \\
25 \mathrm{OHD} \text { at baseline: } \\
30 \mathrm{nmol} / \mathrm{L} \text {. }\end{array}$ & $\begin{array}{l}83 \mu \mathrm{g} / \text { day of vitamin } \mathrm{D}_{3} \text { or placebo in } \\
\text { a double-blind manner for } 1 \text { year } \\
\text { while participation in a } \\
\text { weight-reduction program. }\end{array}$ & $\begin{array}{l}\text { More pronounced decrease } \\
\text { in TNF- } \alpha \text { in vitamin D group } \\
\text { than in placebo group. }\end{array}$ \\
\hline$[52]$ & $\begin{array}{l}218 \text { long-term inpatients. } \\
\text { Mean serum } 25 \mathrm{OHD} \text { at } \\
\text { baseline: } 23 \mathrm{nmol} / \mathrm{L} \text {. }\end{array}$ & $\begin{array}{l}0,400 \text { or } 1200 \mathrm{IU} / \text { day of vitamin } \mathrm{D}_{3} \\
\text { for } 6 \text { months. }\end{array}$ & $\begin{array}{l}\text { No differences in C-reactive } \\
\text { protein. }\end{array}$ \\
\hline$[53]$ & $\begin{array}{l}125 \text { haemodialysis patients. } \\
\text { Mean serum } 25 \mathrm{OHD} \text { at } \\
\text { baseline: } 32 \mathrm{nmol} / \mathrm{L} \text {. }\end{array}$ & $\begin{array}{l}100,000 \mathrm{IU} / \text { month of vitamin } \mathrm{D}_{3} \text { for } \\
15 \text { months. }\end{array}$ & $\begin{array}{l}\text { No differences in C-reactive } \\
\text { protein. }\end{array}$ \\
\hline$[54]$ & $\begin{array}{l}158 \text { haemodialysis patients. } \\
\text { Thirty-nine had diabetes and } \\
54 \text { had hypertension. } \\
\text { Mean serum } 25 \mathrm{OHD} \text { at } \\
\text { baseline: } 55.75 \mathrm{nmol} / \mathrm{L} \text {. }\end{array}$ & $\begin{array}{l}\text { Vitamin } \mathrm{D}_{3} \text { for } 6 \text { months according to } \\
\text { 25OHD serum levels at the baseline: } \\
\text { - 50,000 IU/week for those with } \\
\text { 25OHD serum levels }<15 \mathrm{ng} / \mathrm{mL} \text {; } \\
\text { - 10,000 IU/week for those with } \\
25 \mathrm{OHD} \text { between } 16 \text { and } 30 \mathrm{ng} / \mathrm{mL} \text {; } \\
-2,700 \mathrm{IU} 3 \mathrm{x} \text { week for those with } \\
\text { 25OHD }>30 \mathrm{ng} / \mathrm{mL} \text {. }\end{array}$ & $\begin{array}{l}\text { Significant decrease in } \\
\text { C-reactive protein. }\end{array}$ \\
\hline$[55]$ & $\begin{array}{l}30 \text { haemodialysis patients. } \\
\text { Mean serum } 25 \mathrm{OHD} \text { at } \\
\text { baseline: } 45.5 \mathrm{nmol} / \mathrm{L} \text {. }\end{array}$ & $\begin{array}{l}\text { Weekly supplementation of vitamin } \mathrm{D}_{3} \\
\text { for } 24 \text { weeks: } 50,000 \mathrm{IU} \text { in the first } \\
12 \text { weeks and } 20,000 \mathrm{IU} \text { in the last } \\
12 \text { weeks. }\end{array}$ & $\begin{array}{l}\text { Significant decrease in } \\
\text { C-reactive protein and } \\
\text { interleukin } 6 .\end{array}$ \\
\hline
\end{tabular}

\section{Vitamin D and Type 2 Diabetes}

In contrast to type 1 diabetes, which is related to autoimmune destruction of pancreatic $\beta$ cells, leading to absolute insulin deficiency, type 2 diabetes development involves impaired pancreatic $\beta$ cell function, insulin resistance and inflammation. Although mechanistically unclear, it has been suggested that both environmental and genetic factors seem to be involved in type 2 diabetes development [56]; also, human and experimental data support the role of vitamin D on these pathways $[8,57]$.

Due to the presence of both 1- $\alpha$-hydroxylase and VDR in pancreatic $\beta$ cells, vitamin D is important for insulin synthesis and release $[8,56]$. In rats, vitamin $D$ deficiency induced impairment of insulin secretion and glucose tolerance that was partially corrected after vitamin D replenishment [58,59]. Moreover, vitamin D is also involved in insulin sensitivity by controlling calcium flux through the membrane in both $\beta$ cells and peripheral insulin-target tissues [57].

The initial observations linking vitamin $\mathrm{D}$ to type 2 diabetes in humans came from studies showing that both healthy and diabetic subjects had a seasonal variation of glycemic control [60,61]. Since then, several recent human studies have associated vitamin D status with type 2 diabetes development 
(Table 2). It should be highlighted that after statistical adjustments for potential risk factors of type 2 diabetes, such as body mass index, the association between vitamin $\mathrm{D}$ and type 2 diabetes was attenuated in one study [62] and no longer significant in another one [63]. Almost all studies used serum 25OHD as a biomarker for vitamin D stores, while studies investigating vitamin D intake are scarce.

Table 2. Human studies that associate vitamin D with type 2 diabetes.

\begin{tabular}{|c|c|c|c|}
\hline Ref. & Study design & Subjects included & Main outcome \\
\hline [62] & $\begin{array}{l}\text { Cohort (Mini-Finland } \\
\text { Health Survey) }\end{array}$ & $\begin{array}{l}4097 \text { individuals followed-up } \\
\text { for } 17 \text { years. }\end{array}$ & $\begin{array}{l}\text { The highest versus the lowest serum 25OHD: } \\
\mathrm{RR}=0.70 ; 95 \% \mathrm{CI}=0.42-1.16 \text { ) } \\
p \text { for trend }=0.07)\end{array}$ \\
\hline [63] & $\begin{array}{l}\text { Cohort (Tromsø } \\
\text { Study) }\end{array}$ & $\begin{array}{l}4157 \text { non-smokers and } \\
1962 \text { smokers followed-up } \\
\text { for } 11 \text { years. }\end{array}$ & $\begin{array}{l}\text { Baseline serum } 25 \mathrm{OHD} \text { was inversely } \\
\text { associated with type } 2 \text { diabetes. }\end{array}$ \\
\hline [64] & $\begin{array}{l}\text { Cohort (Nurses' } \\
\text { Health Study) }\end{array}$ & $\begin{array}{l}83,779 \text { women followed-up } \\
\text { for } 20 \text { years. }\end{array}$ & $\begin{array}{l}\text { The highest versus the lowest category of } \\
\text { vitamin } \mathrm{D} \text { intake from supplements: } \\
\mathrm{RR}=0.87 ; 95 \% \mathrm{CI}=0.75-1.00 \\
p \text { for trend }=0.004)\end{array}$ \\
\hline [65] & Nested case-control & 412 cases and 986 controls. & $\begin{array}{l}\text { The highest versus the lowest quartiles of } \\
\text { serum } 25 \mathrm{OHD}: \mathrm{OR}=0.28 \\
(95 \% \mathrm{CI}=0.10-0.81) \text { in men and } \\
\mathrm{OR}=1.14(95 \% \mathrm{CI}=0.60-2.17) \text { in women. }\end{array}$ \\
\hline [66] & Meta-analysis & $\begin{array}{l}\text { Polled data from } 2 \text { cohorts } \\
\text { studies with } 8627 \text { individuals } \\
\text { aged } 40-79 \text { years. }\end{array}$ & $\begin{array}{l}\text { The highest versus the lowest serum 25OHD: } \\
\mathrm{RR}=0.66 ; 95 \% \mathrm{CI}=0.50-0.87\end{array}$ \\
\hline [67] & $\begin{array}{l}\text { Cohort (Framingham } \\
\text { Study) }\end{array}$ & $\begin{array}{l}3066 \text { ( } 1402 \text { men and } \\
1664 \text { women) followed-up } \\
\text { for } 7 \text { years. }\end{array}$ & $\begin{array}{l}\text { A higher } 25 \mathrm{OHD} \text { serum levels is associated } \\
\text { with decreased risk of type } 2 \text { diabetes. }\end{array}$ \\
\hline [6] & Nested case-control & 608 cases and 559 controls. & $\begin{array}{l}\text { The highest versus the lowest serum } 25 \mathrm{OHD} \\
\text { quartile: } \mathrm{OR}=0.52 ; 95 \% \mathrm{CI}=0.33-0.83 \text {. }\end{array}$ \\
\hline [68] & Cross-sectional & $\begin{array}{l}210 \text { individual aged more } \\
\text { than } 40 .\end{array}$ & $\begin{array}{l}\text { Vitamin D deficiency was more common in } \\
\text { diabetic compared to control. }\end{array}$ \\
\hline [69] & Cross-sectional & $\begin{array}{l}668 \text { individuals aged } \\
70-74 \text { years. }\end{array}$ & $\begin{array}{l}\text { Serum } 25 \mathrm{OHD}<50 \mathrm{nmol} / \mathrm{L} \text { doubled the risk } \\
\text { of newly diagnosed type } 2 \text { diabetes. }\end{array}$ \\
\hline [70] & $\begin{array}{l}\text { Cohort (AusDiab } \\
\text { study) }\end{array}$ & $\begin{array}{l}5200 \text { individuals; mean age } \\
51 \text { years. }\end{array}$ & $\begin{array}{l}\text { Each } 25 \mathrm{nmol} / \mathrm{L} \text { increment in serum } 25 \mathrm{OHD} \\
\text { was associated with a } 24 \% \text { reduced risk of } \\
\text { type } 2 \text { diabetes }(\mathrm{OR}=0.76 ; \\
95 \% \mathrm{CI}=0.63-0.92) .\end{array}$ \\
\hline [71] & Cross-sectional & 2465 subjects. & $\begin{array}{l}\text { Serum } 25 \mathrm{OHD} \geq 80 \mathrm{nmol} / \mathrm{L} \text { versus } \\
\leq 37 \mathrm{nmol} / \mathrm{L} \text { in Caucasians: } \mathrm{OR}=0.5 ; \\
95 \% \mathrm{CI}=0.1-0.7 .\end{array}$ \\
\hline [9] & $\begin{array}{l}\text { Systematic review of } \\
7 \text { observational } \\
\text { cohort studies. }\end{array}$ & $\begin{array}{l}238,424 \text { individuals aged } \\
30-75 \text { years. }\end{array}$ & $\begin{array}{l}\text { Vitamin D intake }>500 \text { versus }<200 \mathrm{UI}: \\
\text { risk of type } 2 \text { diabetes } 13 \% \text { lower. Serum } \\
25 \mathrm{OHD} \text { level }(>25 \mathrm{ng} / \mathrm{mL} \text { versus }<14 \mathrm{ng} / \mathrm{mL}) \text { : } \\
\text { risk of type } 2 \text { diabetes } 43 \% \text { lower. }\end{array}$ \\
\hline
\end{tabular}


Based on data from epidemiological studies, vitamin D supplementation is considered a potential and inexpensive therapy not only to decrease the risk, but also to improve glycemic parameters in type 2 diabetic patients [56]. In subjects at high risk of type 2 diabetes and with baseline serum 25OHD level of $26.5 \mathrm{nmol} / \mathrm{L}$, vitamin D supplementation (2000 UI once daily) was associated with improved $\beta$ cell function in adults [72]. Daily intake of vitamin D-fortified yogurt (either with or without added calcium) improved serum 25OHD levels and glycemic status in type 2 diabetic patients with baseline $25 \mathrm{OHD}$ serum level of $44.5 \mathrm{nmol} / \mathrm{L}$. In the same study, an inverse correlation between changes in serum 25OHD and fasting serum glucose and homeostasis model assessment of insulin resistance (HOMA-IR) was observed [73]. In a randomized, controlled, double-blinded intervention study, insulin resistant and vitamin D deficient (serum $25 \mathrm{OHD}<50 \mathrm{nmol} / \mathrm{L}$ ) subjects supplemented with vitamin D (4000 UI, daily, for 6 months) had improved serum 25OHD level, insulin sensitivity and insulin resistance when compared to controls, while no effects were observed on lipid profile, C-reactive protein and insulin secretion [10]. Similarly, in another randomized controlled trial, type 2 diabetes patients with baseline serum $25 \mathrm{OHD}$ concentration $<50 \mathrm{nmol} / \mathrm{L}$ treated with a single dose of vitamin D (100,000 or 200,000 UI) had lower systolic blood pressure than controls, but HOMA-IR was significantly improved only in subjects who received the highest dose [74].

It is important to notice that in a meta-analysis by Pittas et al. [75], among six intervention trials reviewed (five with vitamin $\mathrm{D}$ alone and one with calcium and vitamin $\mathrm{D}$ ), none were able to elicit a remarkable change in measures of glucose intolerance. In 2010, the same group of investigators revisited the question of vitamin D supplementation and plasma glucose [76]. From the randomized controlled trials included, three of them used vitamin D alone, and again no convincing evidence that vitamin D supplementation have benefits on blood glucose control was observed. However, not all studies reported $25 \mathrm{OHD}$ at the baseline and studies vary in the amount of vitamin D, type of vitamin D, length of supplementation, number of subjects, and subject characteristics such as non-diabetic, diabetics, healthy, overweight, insulin resistant, and gender. Thus, it would be important that all future trials describe 25OHD serum levels at the baseline and investigate not only blood glucose but also the role of vitamin $\mathrm{D}$ on glucose tolerance, insulin secretion, insulin sensitivity and ultimately with incident of type 2 diabetes. In order to provide more robust evidences on vitamin $\mathrm{D}$ in both prevention and management of type 2 diabetes, future trials should also investigate the role of higher doses of vitamin D supplementation in larger populations and for longer periods.

Despite the lack of consensus regarding the adequate 25OHD serum levels to prevent and improve glycemic parameters in type 2 diabetes patients, it should be highlighted that the positive effect of vitamin D supplementation was observed when baseline 25OHD serum levels improved to near $80 \mathrm{nmol} / \mathrm{L}$ after the intervention [10,73,74]. Accordingly, data from a cross-section study described that subjects who had $25 \mathrm{OHD}$ serum levels $\geq 80 \mathrm{nmol} / \mathrm{L}$ had decreased risk of developing type 2 diabetes when compared to the ones who had $\leq 37 \mathrm{nmol} / \mathrm{L}[71]$.

Although not uniformly, it was suggested that several genetic polymorphisms in genes related to vitamin D metabolism, such as DBP and VDR, may predispose subjects to type 2 diabetes [56]. Three variants of DBP gene (Gc1f, Gc1s, and Gc2) were associated with differences in oral glucose tolerance in nondiabetic Pima Indians [77]. Although no difference was observed between DBP genotypes regarding plasma glucose concentration, normal glucose tolerance Japanese subjects with Gc1s-2 and 1s-1s genotypes had significantly higher fasting plasma insulin concentration and HOMA-IR than the 
ones with 1f-1f [78]. However, DBP gene polymorphism was not associated with diabetes in while Americans of European origin [79] and in French Caucasians [80].

A similar scenario is observed for VDR genotype. Regarding VDR ApaI polymorphisms, older adults without diabetes that have aa genotype had higher fasting plasma glucose and prevalence of glucose intolerance than those with AA genotype. In the same study, bb genotype of VDR BsmI polymorphism was associated with insulin resistance in subjects with diabetes [81]. VDR polymorphisms were also associated with type 2 diabetes in two Indian case-control studies [82,83]. However, in Polish [84] and Turkish [85] case-control studies, no differences were observed between groups regarding allele frequency of VDR polymorphisms.

\section{Conclusion}

In summary, there is consistent evidence supporting that vitamin D status is related to and is important to regulate some pathways related to type 2 diabetes development. Although experimental studies support the involvement of vitamin D in modulating the inflammatory response, human studies investigating inflammatory biomarkers specifically in subjects with or at high risk of developing type 2 diabetes are scarce. Thus, based on available clinical and epidemiological data, the positive effects of vitamin D seem to be primarily related to its action on insulin secretion and sensitivity and secondary to its action on inflammation. Future studies specifically designed to investigate the role of vitamin D on type 2 diabetes using inflammation as the main outcome are urgently needed in order to provide a more robust link between vitamin D, inflammation and type 2 diabetes. Furthermore, genetic polymorphisms studies are also important in order to identify groups that are more susceptible to vitamin D deficiency and to developing type 2 diabetes in the population.

\section{Acknowledgements}

We acknowledge the support of Fundação de Amparo à Pesquisa do Estado de São Paulo (FAPESP) (grant number: 09/54395-0). C.E.A.C was supported by a fellowship from FAPESP (2010/08386-7).

\section{References}

1. International Diabetes Federation (IDF). Diabetes Atlas Global Burden, Epidemiology and Morbidity. Diabetes and Impaired Glucose Tolerance. Available online: http://www.diabetesaltas.org/ content/diabetes-and-impaired-glucose-tolerance (acessed on 19 October 2011).

2. James, W.P.T. 22nd Marabou Symposium: The changing faces of vitamin D. Nutr. Rev. 2008, 66, 286-290.

3. Melamed, M.L.; Michos, E.D.; Post, W.; Astor, B. 25-hydroxyvitamin D levels and the risk of mortality in the general population. Arch. Intern. Med. 2008, 168, 629-637.

4. Palomer, X.; Gonzalez-Clemente, J.M.; Blanco-Vaca, F.; Mauricio, D. Role of vitamin D in the pathogenesis of type 2 diabetes mellitus. Diabetes Obes. Metab. 2008, 10, 185-197.

5. Chiu, K.C.; Chu, A.; Go, V.L.; Saad, M.F. Hypovitaminosis D is associated with insulin resistance and beta cell dysfunction. Am. J. Clin. Nutr. 2004, 79, 820-825. 
6. Pittas, A.G.; Sun, Q.; Manson, J.E.; Dawson-Hughes, B.; Hu, F.B. Plasma 25-hydroxyvitamin D concentration and risk of incident type 2 diabetes in women. Diabetes Care 2010, 33, 2021-2023.

7. Thorand, B.; Zierer, A.; Huth, C.; Linseisen, J.; Roden, M.; Peters, A.; Koenig, W.; Herder, C. Effect of serum 25-hydroxivitamin D on risk for type 2 diabetes may be partially mediated by subclinical inflammation: Results from the MONICA/RORA Ausburg study. Diabetes Care 2011, 34, 2320-2322.

8. Pittas, A.; Dawson-Hughes, B. Vitamin D and diabetes. J. Sterol. Biochem. Mol. Biol. 2010, 121, 425-429.

9. Mitri, J.; Murau, M.D.; Pittas, A.G. Vitamin D and type 2 diabetes: A systematic review. Eur. J. Clin. Nutr. 2011, 65, 1005-1015.

10. Von Hurst, P.R.; Stonehouse, W.; Coad, J. Vitamin D supplementation reduces insulin resistance in South Asian women living in New Zealand who are insulin resistant and vitamin D deficient-A randomized, placebo-controlled trial. Br. J. Nutr. 2010, 103, 549-555.

11. Pradhan, A. Obesity, Metabolic Syndrome, and Type 2 Diabetes: Inflammatory Basis of Glucose Metabolic Disorders. Nutr. Rev. 2007, 65, S152-S156.

12. Flores, M. A role of vitamin D in low-intensity chronic inflammation and insulin resistance in type 2 diabetes mellitus? Nutr. Res. Rev. 2005, 18, 175-182.

13. Hotamisligil, G.S.; Shargill, N.S.; Spiegelman, B.M. Adipose expression of tumor-necrosisfactor-alpha_-direct role in obesity-linked insulin resistance. Science 1993, 259, 87-91.

14. Cancello, R.; Clement, K. Is obesity an inflammatory illness? Role of low-grade inflammation and macrophage infiltration in human white adipose tissue. BJOG Int. J. Obstet. Gynaecol. 2006, $113,1141-1147$.

15. Lumeng, C.N.; DeYoung, S.M.; Bodzin, J.L.; Saltiel, A.R. Increased inflammatory properties of adipose tissue macrophages recruited during diet-induced obesity. Diabetes 2007, 56, 16-23.

16. Lumeng, C.N.; Bodzin, J.L.; Saltiel, A.R. Obesity induces a phenotypic switch in adipose tissue macrophage polarization. J. Clin. Invest. 2007, 117, 175-184.

17. Gregor, M.F.; Hotamisligil, G.S. Inflammatory mechanisms in obesity. Ann. Rev. Immunol. 2011, 29, 415-445.

18. Zeyda, M.; Stulnig, T.M. Obesity, inflammation, and insulin resistance-a mini-review. Gerontology 2009, 55, 379-386.

19. Arkan, M.C.; Hevener, A.L.; Greten, F.R.; Maeda, S.; Li, Z.W.; Long, J.M.; Wynshaw-Boris, A.; Poli, G.; Olefsky, J.; Karin, M. IKK-beta links inflammation to obesity-induced insulin resistance. Nat. Med. 2005, 11, 191-198.

20. Solinas, G.; Vilcu, C.; Neels, J.G.; Bandyopadhyay, G.K.; Luo, J.L.; Naugler, W.; Grivennikov, S.; Wynshaw-Boris, A.; Scadeng, M.; Olefsky, J.M.; Karin, M. JNK1 in hematopoietically derived cells contributes to diet-induced inflammation and insulin resistance without affecting obesity. Cell Metab. 2007, 6, 386-397.

21. Lebrun, P.; Van Obberghen, E. SOCS proteins causing trouble in insulin action. Acta Physiol. 2008, 192, 29-36.

22. Torres-Leal, F.L.; Fonseca-Alaniz, M.H.; Rogero, M.M.; Tirapegui, J. The role of inflamed adipose tissue in the insulin resistance. Cell Biochem. Funct. 2010, 28, 623-631. 
23. Kennedy, A.; Martinez, K.; Chuang, C.C.; LaPoint, K.; McIntosh, M. Saturated fatty acid-mediated inflammation and insulin resistance in adipose tissue: Mechanisms of action and implications. J. Nutr. 2009, 139, 1-4.

24. Bruun, J.M.; Lihn, A.S.; Verdich, C.; Pedersen, S.B.; Toubro, S.; Astrup, A.; Richelsen, B. Regulation of adiponectin by adipose tissue-derived cytokines: In vivo and in vitro investigations in humans. Am. J. Physiol. Endocrinol. Metab. 2003, 285, E527-E533.

25. Wolf, A.M.; Wolf, D.; Rumpold, H.; Enrich, B.; Tilg, H. Adiponectin induces the anti-inflammatory cytokines IL-10 and IL-1RA in human leukocytes. Biochem. Biophys. Res. Commun. 2004, 323, 630-635.

26. Martini, L.A.; Wood, R.J. Vitamin D status and the metabolic syndrome. Nutr. Rev. 2006, 64, 479-486.

27. Haussler, M.R.; Haussler, C.A.; Bartik, L.; Whitfield, G.K.; Hsieh, J.C.; Slater, S.; Jurutka, P.W. Vitamin D receptor: Molecular signaling and actions of nutritional ligands in disease prevention. Nutr. Rev. 2008, 66, S98-S112.

28. Sigmundsdottir, H.; Pan, J.; Debes, G.F.; Alt, C.; Habtezion, A.; Soler, D.; Butcher, E.C. DCs metabolize sunlight-induced vitamin D3 to "program" T cell attraction to the epidermal chemokine CCL27. Nat. Immunol. 2007, 8, 285-293.

29. Fritsche, J.; Mondal, K.; Ehrnsperger, A.; Andreesen, R.; Kreutz, M. Regulation of 25-hydroxyvitamin D-3-1 alpha-hydroxylase and production of 1 alpha,25-dihydroxyvitamin D-3 by human dendritic cells. Blood 2003, 102, 3314-3316.

30. van Etten, E.; Mathieu, C. Immunoregulation by 1,25-dihydroxyvitamin D-3: Basic concepts. J. Steroid Biochem. Mol. Biol. 2005, 97, 93-101.

31. Liu, P.T.; Stenger, S.; Li, H.Y.; Wenzel, L.; Tan, B.H.; Krutzik, S.R.; Ochoa, M.T.; Schauber, J.; $\mathrm{Wu}, \mathrm{K}$; Meinken, C.; et al. Toll-like receptor triggering of a vitamin D-mediated human antimicrobial response. Science 2006, 311, 1770-1773.

32. Baker, R.G.; Hayden, M.S.; Ghosh, S. NF-kappa B, inflammation, and metabolic disease. Cell Metab. 2011, 13, 11-22.

33. Cohen-Lahav, M.; Shany, S.; Tobvin, D.; Chaimovitz, C.; Douvdevani, A. Vitamin D decreases NF kappa B activity by increasing I kappa B alpha levels. Nephrol. Dial. Transplant. 2006, 21, 889-897.

34. Sadeghi, K.; Wessner, B.; Laggner, U.; Ploder, M.; Tamandl, D.; Friedl, J.; Zügel, U.; Steinmeyer, A.; Pollak, A.; Roth, E.; et al. Vitamin D3 down-regulates monocyte TLR expression and triggers hyporesponsiveness to pathogen-associated molecular patterns. Eur. J. Immunol. 2006, 36, 361-370.

35. Giulietti, A.; van Etten, E.; Overbergh, L.; Stoffels, K.; Bouillon, R.; Mathieu, C. Monocytes from type 2 diabetic patients have a pro-inflammatory profile-1,25-Dihydroxyvitamin D-3 works as anti-inflammatory. Diabetes Res. Clin. Pract. 2007, 77, 47-57.

36. Cohen-Lahav, M.; Douvdevani, A.; Chaimovitz, C.; Shany, S. The anti-inflammatory activity of 1,25-dihydroxyvitamin D-3 in macrophages. J. Steroid Biochem. Mol. Biol. 2007, 103, 558-562.

37. Borges, M.C.; Martini, L.A.; Rogero, M.M. Current perspectives on vitamin D, immune system, and chronic diseases. Nutrition 2011, 27, 399-404. 
38. Jablonski, K.L.; Chonchol, M.; Pierce, G.L.; Walker, A.E.; Seals, D.R. 25-Hydroxyvitamin D deficiency is associated with inflammation-linked vascular endothelial dysfunction in middle-aged and older adults. Hypertension 2011, 57, 63-69.

39. Peterson, C.A.; Heffernan, M.E. Serum tumor necrosis factor-alpha concentrations are negatively correlated with serum 25(OH)D concentrations in healthy women. J. Inflam. 2008, 5, 10.

40. Ngo, D.T.; Sverdlov, A.L.; McNeil, J.J.; Horowitz, J.D. Does Vitamin D modulate asymmetric dimethylarginine and C-reactive protein concentrations? Am. J. Med. 2010, 123, 335-341.

41. Dobnig, H.; Pilz, S.; Scharnagl, H.; Renner, W.; Seelhorst, U.; Wellnitz, B.; Kinkeldei, J.; Boehm, B.O.; Weihrauch, G.; Maerz, W. Independent association of low serum 25-hydroxyvitamin D and 1,25-dihydroxyvitamin D levels with all-cause and cardiovascular mortality. Arch. Intern. Med. 2008, 168, 1340-1349.

42. Bellia, A.; Garcovich, C.; D’Adamo, M.; Lombardo, M.; Tesauro, M.; Donadel, G.; Gentileschi, P.; Lauro, D.; Federici, M.; Lauro, R.; et al. Serum 25-hydroxyvitamin D levels are inversely associated with systemic inflammation in severe obese subjects. Intern. Emerg. Med. 2011, doi:10.1007/s11739-011-0559-x.

43. Ganji, V.; Zhang, X.; Shaikh, N.; Tangpricha, V. Serum 25-hydroxyvitamin D concentrations are associated with prevalence of metabolic syndrome and various cardiometabolic risk factors in US children and adolescents based on assay-adjusted serum 25-hydroxyvitamin D data from NHANES 2001-2006. Am. J. Clin. Nutr. 2011, 94, 225-233.

44. Hyppoenen, E.; Berry, D.; Cortina-Borja, M.; Power, C. 25-Hydroxyvitamin D and Pre-Clinical Alterations in Inflammatory and Hemostatic Markers: A Cross Sectional Analysis in the 1958 British Birth Cohort. PLoS One 2010, 5, e10801.

45. Jorde, R.; Haug, E.; Figenschau, Y.; Hansen, J.B. Serum levels of vitamin D and haemostatic factors in healthy subjects: The Tromso study. Acta Haemat. 2007, 117, 91-97.

46. Vilarrasa, N.; Vendrell, J.; Maravall, J.; Elio, I.; Solano, E.; San Jose, P.; García, I.; Virgili, N.; Soler, J.; Gómez, J.M. Is plasma $25(\mathrm{OH})$ D related to adipokines, inflammatory cytokines and insulin resistance in both a healthy and morbidly obese population? Endocrine 2010, 38, 235-242.

47. Schleithoff, S.S.; Zittermann, A.; Tenderich, G.; Berthold, H.K.; Stehle, P.; Koerfer, R. Vitamin D supplementation improves cytokine profiles in patients with congestive heart failure: A double-blind, randomized, placebo-controlled trial. Am. J. Clin. Nutr. 2006, 83, 754-759.

48. Borazan, A.; Ustun, H.; Cefle, A.; Sekitmez, N.; Yilmaz, A. Comparative efficacy of oral and intravenous calcitriol treatment in haemodialysis patients: Effects on serum biochemistry and cytokine levels. J. Int. Med. Res. 2003, 31, 489-496.

49. Inanir, A.; Ozoran, K.; Tutkak, H.; Mermerci, B. The effects of calcitriol therapy on serum interleukin-1, interleukin-6 and tumour necrosis factor-alpha concentrations in post-menopausal patients with osteoporosis. J. Int. Med. Res. 2004, 32, 570-582.

50. Pittas, A.G.; Harris, S.S.; Stark, P.C.; Dawson-Hughes, B. The effects of calcium and vitamin D supplementation on blood glucose and markers of inflammation in nondiabetic adults. Diabetes Care 2007, 30, 980-986.

51. Zittermann, A.; Frisch, S.; Berthold, H.K.; Goetting, C.; Kuhn, J.; Kleesiek, K.; Stehle, P.; Koertke, H.; Koerfer, R. Vitamin D supplementation enhances the beneficial effects of weight loss on cardiovascular disease risk markers. Am. J. Clin. Nutr. 2009, 89, 1321-1327. 
52. Bjorkman, M.P.; Sorva, A.J.; Tilvis, R.S. C-reactive protein and fibrinogen of bedridden older patients in a six-month vitamin D supplementation trial. J. Nutr. Health Aging 2009, 13, 435-439.

53. Jean, G.; Souberbielle, J.-C.; Chazot, C. Monthly cholecalciferol administration in haemodialysis patients: A simple and efficient strategy for vitamin D supplementation. Nephrol. Dial. Transplant. 2009, 24, 3799-3805.

54. Matias, P.J.; Jorge, C.; Ferreira, C.; Borges, M.; Aires, I.; Amaral, T.; Gil, C.; Crtez, J.; Ferreira, A. Cholecalciferol supplementation in hemodialysis patients: Effects on mineral metabolism, inflammation, and cardiac dimension parameters. Clin. J. Am. Soc. Nephrol. 2010, 5, 905-911.

55. Bucharles, S.; Barberato, S.R.; Stinghen, A.E.M.; Gruber, B.; Piekala, L.; Dambiski, A.C.; Custodio, M.R.; Pecoits-Filho, R. Impact of cholecalciferol treatment on biomarkers of inflammation and myocardial structure in hemodialysis patients without hyperparathyroidism. J. Ren. Nutr. 2011, doi:10.1053/j.jrn.2011.07.001.

56. Takiishi, T.; Gysemans, C.; Bouillon, R.; Mathieu, C. Vitamin D and diabetes. Endocrinol. Metab. Clin. N. Am. 2010, 39, 419-446.

57. Wolden-Kirk, H.; Overbergh, L.; Christesen, H.T.; Brusgaard, K.; Mathieu, C. Vitamin D and diabetes: Its importance for beta cell and immune function. Mol. Cell. Endocrinol. 2011, 347, 106-120.

58. Norman, A.W.; Frnkel, J.B.; Heldt, A.M.; Grodsky, G.M. Vitamin D deficency inhibits pancreatic secretion of insulin. Science 1980, 209, 823-825.

59. Cade, C.; Norman, A.W. Rapid normalization/stimulation by 1,25-dihydroxyvitamin $\mathrm{D}_{3}$ of insulin secretion and glucose tolerance in the vitamin D-deficent rat. Endocrinology 1987, 120, 1490-1497.

60. Campbell, I.T.; Jarrett, R.J.; Keen, H. Diurnal and seasonal variation in oral glucose tolerance: Studies in the Antartic. Diabetologia 1975, 11, 139-145.

61. Behall, K.M.; Scholfield, D.J.; Hallfrisch, J.G.; Kelsay, J.L.; Reiser, S. Seasonal variation in plasma glucose and hormone levels in adult men and women. Am. J. Clin. Nutr. 1984, 40, 1352-1356.

62. Mattila, C.; Knekt, P.; Männistö, S.; Rissanen, H.; Laaksonen, M.A.; Montonen, J.; Reunanen, A. Serum 25-hydroxyvitamin D concentration and subsequent risk of type 2 diabetes. Diabetes Care 2007, 30, 2569-2570.

63. Grimnes, G.; Emaus, N.; Joakimsen, R.M.; Figenschau, Y.; Jenssen, T.; Njølstad, I.; Schirmer, H.; Jorde, R. Baseline serum 25-hydroxyvitamin D concentrations in the Tromsø Study 1994-95 and risk of developing type 2 diabetes mellitus during 11 years of follow up. Diabet. Med. 2010, 27, 1107-1115.

64. Pittas, A.G.; Dawson-Hughes, B.; Li, M.; Van Dam, R.M.; Willett, W.C.; Manson, J.E.; Hu, F.B. Vitamin D and calcium intake in relation to type 2 diabetes in women. Diabetes Care 2006, 29, 650-656.

65. Knekt, P.; Laaksonen, M.; Mattila, C.; Härkänen, T.; Marniemi, J.; Heliövaara, M.; Rissanen, H.; Montonen, J.; Reunanen, A. Serum vitamin D and subsequent occurrence of type 2 diabetes. Epidemiology 2008, 19, 666-671.

66. Laaksonen, M.A.; Knekt, P.; Rissanen, H.; Härkanen, T.; Virtala, E.; Marniemi, J.; Aromaa, A.; Heliövaara, M.; Reunane, A. The relative importance of modifiable potential risk factors of type 2 diabetes: A meta-analysis of two cohorts. Eur. J. Epidemiol. 2010, 25, 115-124. 
67. Liu, E.; Meigs, J.B.; Pittas, A.G.; Economos, C.D.; Mckeown, N.M.; Booth, S.L.; Jacques, P.F. Predicted 25-hydroxyvitamin D score and incident type 2 diabetes in the Framingham offspring study. Am. J. Clin. Nutr. 2010, 91, 1627-1633.

68. Tahrani, A.A.; Ball, A.; Shepherd, L.; Rahim, A.; Jones, A.F.; Bates, A. The prevalence of vitamin D abnormalities in South Asians with type 2 diabetes mellitus in the UK. Int. J. Clin. Pract. 2010, 64, 351-355.

69. Dalgard, C.; Petersen, M.S.; Weihe, P.; Grandjean, P. Vitamin D status in relation to glucose metabolism and type 2 diabetes in septuagenarians. Diabetes Care 2011, 34, 1284-1288.

70. Gagnon, C.; Lu, Z.X.; Magliano, D.J.; Dunstan, D.W.; Shaw, J.E.; Zimmet, P.Z.; Sikaris, K.; Grantham, N.; Ebeling, P.R.; Daly, R.M. Serum 25-hydroxyvitamin D, calcium intake, and risk of type 2 diabetes after 5 years. Diabetes Care 2011, 34, 1133-1138.

71. Brock, K.E.; Huang, W.Y.; Fraser, D.R.; Ke, L.; Tseng, M.; Mason, R.S.; Stolzenberg-Solomon, R.Z.; Freedman, D.M.; Ahn, J.; Peters, U.; et al. Diabetes prevalence is associated with serum 25-hydroxyvitamin D and 1,25-dihydroxyvitamin D in US middle-aged Caucasians men and women: A cross-sectional analysis within the Prostate, Lung, Colorectal and Ovarian Cancer Screening Trial. Br. J. Nutr. 2011, 106, 339-344.

72. Mitri, J.; Dawson-Hughes, B.; Hu, F.B.; Pittas, A.G. Effects of vitamin D and calcium supplementation od pancreatic $\beta$ cell function, insulin sensitivity, and glycemia in adults at high risk of diabetes: The Calcium and Vitamin D for Diabetes Mellitus (CaDDM) randomized controlled trial. Am. J. Clin. Nutr. 2011, 94, 486-494.

73. Nikooyeh, B.; Neyestani, T.R.; Farvid, M.; Alavi-Majd, H.; Houshiarrad, A.; Kalayi, A.; Shariatzadeh, N.; Gharavi, A.; Heravifard, S.; Tayebinejad, N.; et al. Daily consumption of vitamin D- or vitamin D + calcium-fortified yogurt drink improved glycemic conrol in patients with type 2 diabetes: A randomized clinical trial. Am. J. Clin. Nutr. 2011, 93, 764-771.

74. Witham, M.D.; Dove, F.J.; Dryburgh, M.; Sygden, J.A.; Morris, A.D.; Struthers, A.D. The effect of different doses of vitamin $\mathrm{D}_{3}$ on markers of vascular health in patients with type 2 diabetes: A randomised controlled trial. Diabetologia 2010, 53, 2112-2119.

75. Pittas, A.G.; Lau, J.; Hu, F.B.; Dawson-Hughes, B. The role of vitamin D and calcium in type 2 diabetes. A systematic review and meta-analysis. J. Clin. Endocrinol. Metab. 2007, 92, 2017-2029.

76. Pittas, A.G.; Chung, M.; Trikalinos, T.; Mitri, J.; Brendel, M.; Patel, K.; Lichtenstein, A.H.; Lau, J.; Balk, E.M. Systematic review: vitamin D and cardiometabolic outcomes. Ann. Intern. Med. 2010, 152, 307-314.

77. Baier, L.J.; Dobberfuhl, A.A.; Pratley, R.E.; Hanson, R.L.; Bogardus, C. Variations in the vitamin D-binding protein (Gc locus) are associated with oral glucose tolerance in nondiabetic Pima Indians. J. Clin. Endocrinol. Metab. 1998, 83, 2993-2996.

78. Hirai, M.; Suzuki, S.; Hinokio, Y.; Chiba, M.; Akai, H.; Suzuki, C.; Toyota, T. Variations in vitamin D-binding protein (group-specific component protein) are associated with fasting plasma insulin levels in Japanese with normal glucose tolerance. J. Clin. Endocrinol. Metab. 2000, 85, 1951-1953.

79. Klupa, T.; Malecki, M.; Hanna, L.; Sieradzka, J.; Frey, J.; Warram, J.H.; Sieradzki, J.; Krolewski, A.S. Amino acid variats of the vitamin D-binding protein and risk of diabetes in white Americans of European origin. Eur. J. Endocrinol. 1999, 141, 490-493. 
80. Ye, W.Z.; Dubois-Laforgue, D.; Bellanné-Chantelot, C.; Timsit, J.; Velho, G. Variations in the vitamin D-biding protein (Gc locus) and risk of type 2 diabetes mellitus in French Caucasians. Metabolism 2001, 50, 366-369.

81. Oh, J.Y.; Barrett-Connor, E. Association between vitamin D receptor polymorphism and type 2 diabetes or metabolic syndrome in community-dwelling older adults: The Rancho Bernardo Study. Metabolism 2002, 51, 356-359.

82. Bid, H.K.; Konwasr, R.; Aggarwal, C.G.; Gautam, S.; Saxena, M.; Nayak, V.L.; Banerjee, M. Vitamin D receptor (FolkI, BsmI and TaqI) gene polymorphisms and type 2 diabetes mellitus: A North Indian study. Indian J. Med. Sci. 2009, 63, 187-194.

83. Mukhopadhyaya, P.N.; Acharya, A.; Chavan, Y.; Purohit, S.S.; Mutha, A. Metagenomic study of single-nucleotide polymorphisms within cadidate genes associated with type 2 diabetes in an Indian population. Genet. Mol. Res. 2010, 9, 2060-2068.

84. Malecki, M.T.; Frey, J.; Moczulshi, D.; Klupa, T.; Kozek, E.; Sieradzki, J. Vitamin D receptor gene polymorphisms and association with type 2 diabetes mellitus in a Polish population. Exp. Clin. Endocrinol. Diabetes 2003, 111, 505-509.

85. Dilmec, F.; Uzer, E.; Akkafa, F.; Kose, E.; Van Kuilenburg, A.B. Detection of VDR gene ApaI and TaquI polymorphisms in patients with type 2 diabetes mellitus using PCR-RFLP method in Turkish population. J. Diabetes Complicat. 2010, 24, 186-191.

(C) 2012 by the authors; licensee MDPI, Basel, Switzerland. This article is an open access article distributed under the terms and conditions of the Creative Commons Attribution license (http://creativecommons.org/licenses/by/3.0/). 